\title{
A Study of the Interest in Teaching among Teacher Trainees of Shillong
}

\author{
Dr I. Syiem \\ Associate Professor Dept of Education, NEHU Shillong
}

\begin{abstract}
The present study has been conducted to find out the interest level of teacher trainees at the Secondary level. Further, significant differences between sex, type of qualification and locale of teacher trainees in teaching interest has been studied. A sample of 161 Secondary teacher trainees were randomly selected from two College of Teacher Education, Shillong City. The data was collected using the Kakar Interest in Teaching Scale developed by Dr S.B.Kakar 1985. The results revealed that there is no significant difference between male and female, graduate and post graduate teacher trainees in interest in teaching. However significant difference was found between rural and urban teacher trainees in interest in teaching.
\end{abstract}

\section{Introduction}

Teachers hold a very important place in the educational system and an influential figure in the lives of students. There are many factors which contribute towards effective and good teachers. Besides, knowledge of subject matter, professionalism etc interest of the teacher in teaching is the most important. Interest is the vital force that stirs the entire process of teaching and learning. All attempts are aimed to make students interested in learning. If teachers are found wanting in interest then students lives and learning experiences will be jeopardised.

\section{Objectives}

1. To find out the interest in teaching of Secondary teacher trainees of Shillong City.

2. To find out the difference between male and female teacher trainees in interest in teaching

3. To find out the difference between graduate and postgraduate teacher trainees in interest in teaching

4. To find out the difference between rural and urban teacher trainees in interest in teaching

\section{Hypotheses}

- $\quad$ There is no significant difference between male and female teacher trainees in interest in teaching

- $\quad$ There is no significant difference between graduate and postgraduate teacher trainees in interest in teaching

- There is no significant difference between rural and urban teacher trainees in interest in teaching Sample

The researcher selected 161 teacher trainees by random sampling from two College of Teacher Education of Shillong City.

\section{Tool Used}

The Kakar Interest in teaching Scale was used to measure the interest in teaching of Secondary teacher trainees. The KITS is a self administering scale with five choices given to each item and the credit was to be given to the best choice selected. The maximum score obtainable was twenty-seven (one for each correct answer).

\section{Statistical Analysis}

Percentage was used to find out the level of interest in teaching and t-test was applied to find out the significant differences.

\section{Result and discussion}

It may be observed from the overall score that majority $55.21 \%$ Secondary teacher trainees have average interest in teaching followed by $39.26 \%$ and $5.52 \%$ have low and high interest in teaching respectively. In the case of sex, type of qualification and locale the same trend follows whereby majority of teacher trainees have average interest in teaching and a small percentage have high and low interest in teaching. The data 
obtained is inclined towards the normal curve where majority of the distribution are concentrated round the center and a small percentage taper from this point to the left or right. The teacher trainees have come from different backgrounds with average interest in teaching. With the kind of environment that they will be exposed to, it is hopeful that there interest in teaching will also develop and grow positively.

On comparing the teacher trainees on the basis of sex, type of qualification and locale it was discovered that no significant difference was found between male and female, graduate and post graduate teacher trainees . Thus, the hypotheses are retained in both cases. The probable reason maybe that Interest in teaching is not attributed to sex or type of qualification but to passion and seriousness of teaching students. This finding is in line with the findings of Sasikala (2012) where no significant differences was found between male and female, postgraduate and undergraduate BEd trainees in interest in teaching.

However, significant difference was found between rural and urban teacher trainees. The mean score of rural and urban teachers was 10.6 and 9.41 respectively. The mean score of rural trainees was more than that of urban trainees which manifested significant difference with $t$ value being 1.98 which is significant at 0.05 level. Thus, the hypothesis is rejected. The probable reason maybe that rural teacher trainees feel the need of having better schools in the rural areas which are posed with many difficulties. In addition, rural schools fail to attract and retain teachers and administrators, thus rural teacher trainees desire to make a tangible difference and have a lasting impact on student's lives.

\section{Conclusion}

It maybe concluded that sex and educational qualification do not determine the interest in teaching of teacher trainees. It is believed that passion, desire and seriousness will go a long way in influencing the teaching interest of individuals. It is hopeful that the interest level of teacher trainees will be influenced and magnified with the acquisition of training .

\section{References}

[1]. Mangal, S.K. Essentials of Educational Psychology, New Delhi: PHL Learning Private Limited, 2011

[2]. Mishra, S.K. "A Study of Self-Concept and Interests in Teaching of Pre-Service Teachers of Secondary Level” in International Journal of Advancements in Research and Technology Vol 1, Issue 5, October 2012

[3]. Sasika V. "Dignity and Interest of BEd Teacher Trainees in Chennai District" in International Journal of Scientific and Research Publication, Vol 2, Issue 11 November 2012 